\title{
E3 Ubiquitin-Protein Ligase Midline-1
}

National Cancer Institute

\section{Source}

National Cancer Institute. E3 Ubiquitin-Protein Ligase Midline-1. NCI Thesaurus. Code C75732.

E3 ubiquitin-protein ligase Midline-1 (667 aa, $75 \mathrm{kDa}$ ) is encoded by the human MID1 gene. This protein is involved in protein ubiquitination and may influence microtubule dynamics. 